\title{
Lifetime reproductive success in seabirds: interindividual differences and implications for conservation*
}

\author{
JUAN MORENO \\ Departamento de Ecología Evolutiva, Museo Nacional de Ciencias Naturales-CSIC, J. Gutiérrez Abascal 2, \\ E-28006 Madrid, Spain. E-mail: jmoreno@mncn.csic.es
}

\begin{abstract}
SUMMARY: Seabirds share certain life history traits, most species being relatively longlived and reproducing at a low rate. Long-term population studies of seabirds have revealed that lifetime reproductive success differs widely among individuals, and that only a minor fraction of the population contributes importantly to future generations. These individuals have traditionally been termed of high "parental quality". Quality is often defined tautologically as breeding success. Determinants of parental quality, and ways to measure it a priori without relying on breeding success, remain a challenge in seabird ecology. Parental health state and immunocompetence have been shown to be associated with breeding date, egg size, chick growth rate and breeding success in several field studies and may allow the identification of good breeders. Identifying the "high quality" fraction in a population may be worthwhile in order to better guarantee the productivity of declining populations.
\end{abstract}

Key words: conservation, health, immunocompetence, life histories, lifetime reproductive success, parental quality, seabirds.

RESUMEN: ÉXITO REPRODUCTOR A LO LARGO DE LA VIDA EN LAS AVES MARINAS: DIFERENCIAS ENTRE INDIVIDUOS E IMPLICACIONES PARA LA CONSERVACIÓN. - Las aves marinas comparten ciertas características en sus estrategias vitales, siendo la mayoría de las especies de vida larga y reproduciéndose a una baja tasa. Los estudios poblacionales a largo plazo en aves marinas han revelado que el éxito reproductor a lo largo de la vida difiere grandemente entre individuos, y que solo una pequeña fracción de la población contribuye de forma importante a las generaciones futuras. Estos individuos han sido tradicionalmente denominados como de alta "calidad parental". No obstante, la calidad es a menudo definida tautológicamente como éxito reproductor. Los determinantes de la calidad parental, y las formas de medirlo a priori, sin recurrir al éxito reproductor, continuan siendo un desafío para la ecología de las aves marinas. El estado de salud parental y la inmunocompetencia han resultado estar asociadas a la fecha de reproducción, tamaño del huevo, tasa de crecimiento y éxito reproductor en varios estudios de campo y podrían permitir la identificación de los buenos reproductores. Identificar la fracción de "alta calidad" en una población pudiera ser útil para garantizar mejor la productividad de poblaciones en declive.

Palabras clave: aves marinas, calidad parental, conservación, estrategias vitales, inmunocompetencia, salud.

\section{INTRODUCTION}

The widespread idea that most breeding individuals in natural populations contribute to succeeding generations has been shattered in the last decades by

\footnotetext{
*Received July 6, 2001. Accepted July 25, 2002.
}

a series of long-term studies, many of them on birds. Newton (1995) summarised the information resulting from these studies as follows: (1) a large proportion of young that are raised to independence die before they can breed; (2) not all the individuals which survive to attempt breeding subsequently produce offspring and (3) successful individuals vary 
TABLE 1. - Proportion of any one generation of fledglings that breed, and proportions of breeders that raise some young throughout their lifetime and produce half the young in the next generation.

\begin{tabular}{lccc}
\hline & $\begin{array}{c}\text { Proportion fledglings } \\
\text { that breed }\end{array}$ & $\begin{array}{c}\text { Proportion breeders raising } \\
\text { half next generation } \\
\text { some young }\end{array}$ \\
\hline Blue tit Parus caeruleus & 0.14 & 0.93 & 0.21 \\
Kingfisher Alcedo atthis & 0.19 & 0.95 & 0.32 \\
Meadow pipit Anthus pratensis & 0.28 & 0.79 & 0.25 \\
Sparrowhawk Accipiter nisus & 0.28 & 0.81 & 0.18 \\
Ural owl Strix uralensis & 0.28 & 0.96 & 0.21 \\
Osprey Pandion haliaetus & 0.29 & 0.59 & 0.16 \\
Barnacle goose Branta leucopsis & 0.58 & & \\
\hline
\end{tabular}

Based on studies reported in Newton (1989).

greatly in productivity. It is this latter point which is worth emphasising, as the variation revealed in these studies is really striking (Table 1 ). We are not as much concerned with the proportions of fledged or independent young that actually breed successfully, as with the proportions of individuals breeding at least once (i.e. individuals which we can find breeding in a population in a certain season). Actually, in 7 bird studies dealing with species ranging from the blue tit (Parus caeruleus) to the barnacle goose (Branta leucopsis), between 16 and 32\% of breeders produced half the next generation (Table 1).

If we consider only seabirds and separate by sex, one third of breeders do not raise any young (Table 2). Also, two thirds or more of raised young do not become new breeders; hence most parents raising young never pass on their genes to future generations. In the kittiwake, although most breeders raise some young during their lifetime, only $41 \%$ of male and $50 \%$ of female breeders succeed in passing on their genes to the next generation. This is a very conservative estimate as most of these birds actually raise very few offspring. As an example, a third of the males and a fifth of the females that manage to raise some young during their lifetime in the short- tailed shearwater (Puffinus tenuirostris) raise only one chick. In this latter study, half of the chicks are produced by $15 \%$ of the adults.

\section{FACTORS EXPLAINING LIFETIME REPRODUCTIVE SUCCESS (LRS)}

Seabirds are mostly long-lived, prudent reproducers, and long-term population studies have revealed that a large part of the variance in LRS is actually due to breeding lifespan (Table 3). This effect is most striking for species with a higher number of breeding years (compare the short-tailed shearwater with the red-billed gull Larus novaehollandiae). The long-lived individuals are in most cases the ones contributing most to the future genepool. This suggests a strong selection for viability in seabird populations. This effect may consist of two main components: (1) more breeding seasons implying more chances to raise young; and (2) the association between breeding success and breeding experience in most seabirds studied. This effect of breeding experience or age is very general (Moreno, 1998) and suggests that the last years of reproduc-

TABLE 2. - Proportion of fledged young that breed and proportions of breeders that raise some young and some recruits throughout their lifetime in several seabird species.

\begin{tabular}{|c|c|c|c|c|}
\hline & & Prop. fledged young that breed & that raise young & recruits \\
\hline $\begin{array}{l}\text { Little blue penguin } \\
\text { Eudyptula minor }\end{array}$ & $\begin{array}{l}\text { Males } \\
\text { Females }\end{array}$ & $\begin{array}{l}0.35 \\
0.28\end{array}$ & $\begin{array}{l}0.57 \\
0.64\end{array}$ & $\begin{array}{l}0.20 \\
0.18\end{array}$ \\
\hline $\begin{array}{l}\text { Short-tailed shearwater } \\
\text { Puffinus tenuirostris }\end{array}$ & $\begin{array}{l}\text { Males } \\
\text { Females }\end{array}$ & $\begin{array}{l}0.73 \\
0.69\end{array}$ & $\begin{array}{l}0.28 \\
0.31\end{array}$ & \\
\hline $\begin{array}{l}\text { Red-billed gull } \\
\text { Larus novaehollandiae }\end{array}$ & $\begin{array}{l}\text { Males } \\
\text { Females }\end{array}$ & $\begin{array}{l}0.22 \\
0.18\end{array}$ & $\begin{array}{l}0.64 \\
0.61\end{array}$ & $\begin{array}{l}0.17 \\
0.24\end{array}$ \\
\hline $\begin{array}{l}\text { Kittiwake } \\
\text { Rissa tridactyla }\end{array}$ & $\begin{array}{l}\text { Males } \\
\text { Females }\end{array}$ & $\begin{array}{l}0.34 \\
0.42\end{array}$ & $\begin{array}{l}0.95 \\
0.96\end{array}$ & $\begin{array}{l}0.41 \\
0.50\end{array}$ \\
\hline
\end{tabular}

Based on studies by Dann and Cullen (1990), Wooller et al. (1988), Mills (1989) and Coulson (1988a). 
TABLE 3. - Effects of breeding lifespan on lifetime reproductive success ( $\mathrm{r}^{2}$ from regression analyses) and breeding lifespan in years for several seabird species.

\begin{tabular}{|c|c|c|c|}
\hline & \multicolumn{2}{|c|}{$\begin{array}{l}\text { Effect of breeding } \\
\text { lifespan }\left(\mathrm{r}^{2}\right) \text { on LRS }\end{array}$} & $\begin{array}{c}\text { Breeding } \\
\text { lifespan (years) }\end{array}$ \\
\hline Fulmar & Males & 61 & 21 \\
\hline Fulmarus glacialis & Females & 54 & 21 \\
\hline $\begin{array}{l}\text { Short-tailed shearwater } \\
\text { Puffinus tenuirostris }\end{array}$ & & 98 & 28 \\
\hline Little blue penguin & Males & 74 & 12 \\
\hline Eudyptula minor & Females & 81 & 15 \\
\hline Kittiwake & Males & 83 & 20 \\
\hline Rissa tridactyla & Females & 80 & 20 \\
\hline Red-billed gull & Males & 31 & 7 \\
\hline Larus novaehollandiae & Females & 29 & 9 \\
\hline
\end{tabular}

$\overline{\text { From studies by Ollason and Dunnet (1988), Wooller et al. (1989), }}$ Dann and Cullen (1990), Coulson (1988a) and Mills (1989).

TABLE 4. - Percentage of variability explained by life-history traits other than longevity in several seabird species.

\begin{tabular}{llc}
\hline & Trait & \% of variability in LRS \\
\hline Fulmar & Fecundity & 12 \\
Fulmarus glacialis & Offspring survival & 48 \\
Kittiwake & Fecundity & 7 \\
Rissa tridactyla & Offspring survival & 4 \\
& & \\
Red-billed gull & Mean lifetime laying date & Females \\
Larus novaehollandiae & Males & 15 \\
& &
\end{tabular}

From studies by Ollason and Dunnett (1988), Coulson (1988a) and Mills (1989).

tion in long-lived seabirds may be crucial for LRS. However, the linearity suggested in the associations found (Coulson, 1988a; Dann and Cullen, 1990) indicates that the effect of experience/age is not as important as one might think based on the seabird literature.

A considerable part of the variation in LRS is due to factors unrelated to longevity. These may be breeding frequency, egg size, breeding date or mate retention (Table 4). There is also a high consistency in fitness-related breeding parameters between years expressed as repeatability (Table 5). However, one should beware of repeatabilities obtained for a few years, as age effects may explain part of this consistency (Catry, 1999). Consistency in breeding performance has been interpreted as being due to differences between breeders in a highly elusive property called "parental quality". Parental quality is a widely used term in the seabird literature and usually refers to consistent differences in some aspect of breeding success (e.g. Nisbet et al., 1998; Wendeln and Becker, 1999). There is a striking circularity in this description, as reproductive success is used to define parental quality, which is then used to explain differences in the same variable used in the definition. As such, parental quality is non-explanatory and just a catchword used to hide our ignorance of what is really happening. In some studies, parental quality is simply the variation in breeding performance which cannot be explained by other measured variables (Coulson and Porter, 1985; Saether et al., 1997).

To avoid tautologous arguments it is necessary to define parental quality in terms of something different from reproductive success. One way is the same as has been proposed by philosophers of biology to avoid the tautology in the definition of natural selection as "the survival of the fittest". Using an approach similar to Brandon (1990), we could define parental quality of an individual breeder as "the propensity to obtain a high reproductive success in a certain environment". Lightning may kill a high-quality parent before the end of reproduction, but that individual would still have a high propensity to breed successfully. Once the philosophical side is solved, we confront the operational problem: is there any way to establish this propensity independently of actual breeding success? I think this is a crucial problem in seabird ecology for two reasons: (1) in basic science, it is necessary to determine what traits underlie parental quality to understand how variation in these presumably strongly selected traits is maintained (the alternative of no variation is unrealistic because we know that there is a great

TABLE 5. - Individual consistency in measures related to reproductive success expressed as repeatability (r) or percentage of variation explained by individuals.

\begin{tabular}{lcc}
\hline & Trait & Consistency \\
\hline $\begin{array}{l}\text { Chinstrap penguin } \\
\text { Pygoscelis antarctica }\end{array}$ & Hatching date & $\mathrm{r}=0.89$ \\
$\begin{array}{l}\text { Fulmar } \\
\text { Fulmarus glacialis }\end{array}$ & $\begin{array}{c}\text { Laying date } \\
\text { explained }\end{array}$ & $33 \%$ variation \\
$\begin{array}{l}\text { Common murre } \\
\text { Uria aalge }\end{array}$ & Laying date & $\mathrm{r}=0.20$ \\
$\begin{array}{l}\text { Arctic skua } \\
\text { Stercorarius parasiticus }\end{array}$ & $\begin{array}{c}\text { Clutch volume } \\
\text { Chick growth }\end{array}$ & $\mathrm{r}=0.45$ \\
Kittiwake & $\mathrm{r}=0.73$ \\
Rissa tridactyla & Breeding success & $23 \%$ variation \\
\hline
\end{tabular}

From studies by Moreno et al. (1998), Hatch (1990), Sydeman and Eddy (1995), Phillips and Furness (1998) and Thomas and Coulson (1988). 
TABLE 6. - Correlation coefficients for associations of longevity with traits related to breeding performance in several seabird species.

\begin{tabular}{|c|c|c|c|}
\hline & Sex & Trait & Correlation \\
\hline Fulmar Fulmarus glacialis & $\begin{array}{l}\text { Males } \\
\text { Females }\end{array}$ & $\begin{array}{l}\text { Fledging success } \\
\text { Fledging success }\end{array}$ & $\begin{array}{l}0.22(\mathrm{p}<0.05) \\
0.26(\mathrm{p}<0.05)\end{array}$ \\
\hline Kittiwake Rissa tridactyla & & Chicks fledged & positive assoc. \\
\hline Red-billed gull Larus novaehollandiae & Females & First laying date & $-0.36(\mathrm{p}<0.01)$ \\
\hline
\end{tabular}

From studies by Ollason and Dunnett (1988), Coulson (1988a) and Mills (1989).

deal of variation); and (2) in applied science, this understanding may help to identify the fraction of the population which will succeed in producing young, making it possible to either protect it or destroy it (culling).

A related question is whether individuals with a high viability (i.e. those with a propensity to attain a long life), can also be detected, and whether they are those with a high parental quality (Table 6). In some studies, reproductive rate and survival rate are significantly correlated (Table 6), which indicates that good parents are the long-lived individuals contributing to future generations, although more data are needed to strengthen this conclusion. However, this finding should not be interpreted as an absence of reproductive costs, as some seabird ecologists have stated (e.g. Coulson, 1988b). To detect life-history trade-offs one has to compare individuals with the same level of resources, i.e. one has to randomise reproductive effort levels among individuals (Stearns, 1992; Roff, 1992).

\section{HOW CAN PARENTAL QUALITY BE MEASURED?}

This positive correlation between fecundity and survival leads to our next question. In what crucial resources do the poor reproducers/survivors differ from the good ones? Seabirds offer the advantage that they do not inhabit territories, so resources must come from some other source than territoriality. The last question is related to the search for an operational measure of parental quality. We are looking for the basis of the propensity to survive and reproduce in a certain environment. This sounds like searching for the substrate of adaptedness or fitness, something which is not recommended by philosophers of biology like Brandon (1990). However, we are not dealing here with philosophical issues, but with operational ones. We need a rough approximation to adaptedness here and now, which may help us to detect the good performers. If we have only resources to protect certain individuals in a population from destruction or impairment of reproduction, these are the only ones worth fighting for, as the rest are to a certain degree 'living dead' for evolution.

There are several variables which could give a hint about immediate reproductive prospects (Table 7). Condition measured non-destructively as mass in relation to structural size is probably less directly related to quality as it fluctuates too much in the short term. Fat or protein reserves may offer another operational measure of quality but require careful standardisation with respect to breeding stage, as reserve storage and utilisation may depend on the demands imposed by different breeding stages (Moreno, 1989). Fluctuating asymmetry of bilateral traits (Møller, 1999) also has its problems of inter-

TABLE 7. - Potential nondestructive measures of phenotypic quality which can be used to predict the reproductive performance of individuals a priori.

- Condition as mass in relation to structural size: is problematic as it fluctuates too much in the short term

- Fat or protein reserves: may offer another operational measure of quality but require careful standardisation with respect to breeding stage, as reserve storage and utilisation may depend on the demands imposed by different breeding stages

- Fluctuating asymmetry: related to developmental instability; contentious for interindividual comparisons, difficult to measure correctly

- Ptilochronology: related to conditions during moult, indirect association with conditions while breeding

- Locomotory capacity: could indicate something about the propensity to evade predators or forage efficiently, but is difficult to measure in the field in a standardised way

- Health state:

healthy individuals have apparently the necessary resources to defend themselves against ubiquitous pathogens, can be derived from haematological measures

- Immunocompetence: is the substrate of health state; good health may be due to a high immunocompetence or to lack of pathogens 
pretation. Locomotory capacity could indicate something about the propensity to evade predators or forage efficiently, but is difficult to measure in the field in a standardised way.

One promising avenue of research in the search for the basis of quality is general health state. Healthy individuals apparently have the necessary resources to defend themselves against ubiquitous pathogens. Finally we have immunocompetence, which is the substrate of health state. Good health may be due to a high immunocompetence or to lack of pathogens. Only the first association represents the propensity to survive, the other is just the consequence of external variation. Of course, all measures requiring the destruction of the study animals are completely unsuitable for our purposes. Is there any evidence linking some of these traits to actual reproductive success or survival probability? I have tried a first step in this direction through two recent studies on penguins. In the first performed on the chinstrap penguin on Deception Island, Antarctica, we were able to measure some variables related to health state and cell-mediated immunity in early and late breeders with a two-week difference in breeding date (Moreno et al., 1998). We used leukocyte counts in blood smears and the PHA response test to that end. We measured these variables at hatching of the chicks. We found that early breeders had symptoms of a better health than late breeders as evidenced by lower numbers of lymphocytes and heterophils and higher levels of T-cell-mediated immunocompetence. Breeding date has important implications for reproductive success in this population (Viñuela et al., 1996). Thus immunocompetence may assist us in identifying early and therefore successful breeders in this population. In Magellanic penguins breeding on the Atlantic coast of Patagonia, we measured hematological variables related to prior infection at hatching of their chicks (Moreno et al., 2002). We found that females with leukocytosis laid smaller eggs, raised chicks with slow growth and failed in raising young to a higher degree than females with better health indicators. These studies pinpoint the importance of health and immunocompetence as indicators of parental quality in seabirds, but they are only a first step.

The detected variation in immunocompetence in wild populations may indicate either that this trait has a low heritability or that its genetic architecture is too complex to allow erosion of existant variation through selection (Merilä and Sheldon, 1999). The study of the genetic and environmental components
TABLE 8. - Percentage of variation explained by nest of origin (genetic component) and statistical significance of its effect on cellmediated immunity in cross-fostering studies of different bird species.

\begin{tabular}{lcc}
\hline Species & $\begin{array}{c}\text { Percentage of } \\
\text { variation explained }\end{array}$ & Significance \\
\hline $\begin{array}{l}\text { American kestrel } \\
\text { Falco sparverius }\end{array}$ & $12 \%$ & $\mathrm{p}<0.05$ \\
$\begin{array}{l}\text { Great tit } \\
\text { Parus major }\end{array}$ & $15 \%$ & $\mathrm{p}<0.001$ \\
$\begin{array}{l}\text { Pied flycatcher } \\
\text { Ficedula hypoleuca }\end{array}$ & $9.7 \%$ & $\mathrm{NS}$ \\
$\begin{array}{l}\text { Swallow } \\
\text { Hirundo rustica }\end{array}$ & $20.1 \%$ & $\mathrm{p}<0.01$ \\
\end{tabular}

$\overline{\text { From studies by Tella et al. (2000), Brinkhof et al. (1999), Soler et }}$ al. (2003) and Saino et al. (1997).

of immunocompetence is still in its infancy although studies on a few non-seabird species suggest that the heritable component measured in cross-fostering studies is small but significant (Table 8).

A typical flawed argument expressed by some seabird ecologists when confronted with the need to monitor health state or immunocompetence is that it is only food availability that determines reproductive success, with parasites and pathogens looking from the sidelines. This argument confuses the environmental factor affecting reproductive success or mortality with the actual physiological mechanism determining proximately death or reproductive failure. It is not food scarcity which directly kills the animals or leads them to abandon their young but the increasing foraging costs interacting with condition and health state. When food gets scarce, some individuals survive or manage to breed and others do not. What determines the difference between these two categories of individuals? Here lies the crux of the matter because food is scarce for all.

\section{IMPLICATIONS FOR CONSERVATION}

There is a further added need to monitor immunocompetence in seabird populations. Global change in pollutant levels, radiation incidence and climate may already be affecting the immunocompetence of seabirds (Sagerup et al., 2000), as they are doing for the more publicised marine mammals. Before confronting a sudden breakdown in immunocompetence of endangered seabirds, we should try to get baseline levels on populations little affected by human-induced changes yet. Sudden mass mor- 
talities in the future may be associated with changes in immune defenses if we know what to expect. As a general point, the neglect until present of the immune system in ecological and conservation studies (Sheldon and Verhulst, 1996) should be replaced by a fuller consideration of its importance for life histories and population dynamics.

\section{ACKNOWLEDGEMENTS}

Eduardo Mínguez invited me to give a plenary talk with a topic of my choosing at the MEDMARAVIS conference in Benidorm in October 2000. My studies on Chinstrap and Magellanic penguins have been financed by grant ANT94-0036 (Spanish Antarctic Research Programme) and an Iberoamerican Cooperation Grant from the Spanish Ministry of Education and Culture respectively.

\section{REFERENCES}

Brandon, R.N. - 1990. Adaptation and Environment. Princeton University Press, Princeton.

Brinkhof, M.W.G., P. Heeb, M. Kölliker and H. Richner. - 1999. Immunocompetence of nestling great tits in relation to rearing environment and parentage. Proc. R. Soc. Lond. B, 266: 2315-2322.

Catry, P. - 1999. Short-lived repeatabilities in long-lived great skuas: implications for the study of individual quality. Oikos, 84: 473-479.

Coulson, J.C. - 1988a. Lifetime reproductive success in the Blacklegged Kittiwake (Rissa tridactyla). In: H. Ouellet (ed.), Acta XIX Congressus Internationalis Ornithologici, pp. 2140-2147. University of Ottawa Press, Ottawa.

Coulson, J.C. - 1988b. Reproductive success of Kittiwake gulls, Rissa tridactyla. In: T.H. Clutton-Brock (ed.), Reproductive success, pp. 251-262. Chicago University Press, Chicago.

Coulson, J.C. and J.M. Porter. - 1985. Reproductive success of the kittiwake Rissa tridactyla: the roles of clutch size, chick growth rates, and parental quality. Ibis, 127: 450-466.

Dann, P. and J.M. Cullen. - 1990. Survival, patterns of reproduction, and lifetime reproductive output in Little Blue Penguins (Eudyptula minor) on Phillip Island, Victoria, Australia. In: L.S. Davis and J.T. Darby (eds.), Penguin Biology, pp. 63-84. Academic Press, San Diego.

Hatch, S.A. - 1990. Individual variation in behavior and breeding success of Northern fulmars. Auk, 107: 750-755.

Merilä, J. and B.C. Sheldon. - 1999. Genetic architecture of fitness and nonfitness traits: empirical patterns and development of ideas. Heredity, 83: 103-109.

Mills, J.A. - 1989. Red-billed Gull. In: I. Newton (ed.), Lifetime Reproduction in Birds, pp. 387-404. Academic Press, London.

Møller, A.P. - 1999. Asymmetry as a predictor of growth, fecundity and survival. Ecol. Letters, 2: 149-156.

Moreno, J. - 1989. Strategies of mass change in breeding birds. Biol. J. Linn. Soc., 37: 297-310.
Moreno, J. - 1998. The determination of seasonal declines in breeding success in seabirds. Etología, 6: 17-31.

Moreno, J., A. De León, J.A. Fargallo and E. Moreno. - 1998. Breeding time, health and immune response in the Chinstrap penguin Pygoscelis antarctica. Oecologia, 115: 312-319.

Moreno, J., P. Yorio, P. García-Borboroglu, J. Potti and S. Villar. 2002. Health state and reproductive output in Magellanic penguins (Spheniscus magellanicus). Ethol. Ecol. Evol. 14: 19-28.

Newton, I. - 1989. Lifetime Reproduction in Birds. Academic Press, London.

Newton, I. - 1995. The contribution of some recent research on birds to ecological understanding. J. Anim. Ecology, 64: 675-698.

Nisbet, I.C.T., J.A. Spendelow, J.S. Hatfield, J.M. Zingo and G.A. Gough. - 1998. Variations in growth of roseate tern chicks: II. Early growth as an index of parental quality. Condor, 100: 305-315.

Ollason, J.C. and G.M. Dunnet. - 1988. Variation in breeding success in fulmars. In: T.H. Clutton-Brock (ed.), Reproductive success:, pp. 263-278. Chicago University Press

Phillips, R.A. and R.W. Furness. - 1998. Repeatability of breeding parameters in Arctic Skuas. J. Avian Biol., 29: 190-196.

Roff, D. - 1992. The Evolution of Life Histories. Chapman and Hall, London.

Sagerup, K., E.O. Henriksen, A. Skorping, J.U. Skaares and G.W. Gabrielsen. - 2000. Intensity of parasitic nematodes increases with organochlorine levels in the glaucous gull. J. Appl. Ecol., 37: 532-539.

Saether, B.E., S.H. Lorentsen, T. Tveraa, R. Andersen, R. and H.C. Pedersen. - 1997. Size-dependent variation in reproductive success of a long-lived seabird, the Antarctic petrel (Thalassoica antarctica). Auk, 114: 333-340.

Saino, N., S. Calza and A.P. Møller. - 1997. Immunocompetence of nestling barnswallows in relation to brood size and parental effort. J. Anim. Ecol., 66: 827-836.

Sheldon, B.C. and S. Verhulst. - 1996. Ecological immunology: costly parasite defence and trade-offs in evolutionary ecology. Trends Ecol. Evol., 11: 317-321.

Soler, J.J., J. Moreno and J. Potti. - 2003. Environmental, genetic and maternal components of immunocompentence of nestling pied flycatchers from a cross-fostering study. Evol. Ecol. Res., 5: $259-272$

Stearns, S.C. 1992. - The Evolution of Life Histories. Oxford University Press, Oxford.

Sydeman, W.J. and J.O. Eddy. - 1995. Repeatability in laying date and its relationship to individual quality for Common Murres. Condor, 97: 1048-1052.

Tella, J.L., G.R. Bortolotti, M.G. Forero and R.D. Dawson. - 2000 Environmental and genetic variation in T-cell-mediated immune response of fledgling American kestrels. Oecologia, 123: 453-459.

Thomas, C.S. and J.C. Coulson. - 1988. Reproductive success of kittiwake gulls, Rissa tridactyla. In: T.H. Clutton-Brock (ed.), Reproductive Success, pp. 251262. Chicago University Press, Chicago.

Viñuela, J., J. Moreno, L.M. Carrascal, J.J. Sanz, J.A. Amat, M. Ferrer, J. Belliure and J.J. Cuervo. - 1996. The effect of hatching date on parental care, chick growth, and chick mortality in the chinstrap penguin Pygoscelis antarctica. J. Zool., 240: 51-58.

Wendeln, H. and P.H. Becker. - 1999. Effects of parental quality and effort on the reproduction of common terns. J. Anim. Ecol., 68: $205-214$

Wooller, R.D., J.S. Bradley, D.L. Serventy and I.J. Skira. - 1988. Factors contributing to reproductive success in Short-tailed Shearwaters (Puffinus tenuirostris). In: H. Ouellet (ed.), Acta XIX Congressus Internationalis Ornithologici, pp. 848-856. University of Ottawa Press, Ottawa.

Wooller, R.D., J.S. Bradley, I.J. Skira and D.L. Serventy. - 1989. Short-tailed Shearwater. In: I. Newton (ed.), Lifetime Reproduction in Birds, pp. 405-417. Academic Press, London. 